Formatif: Jurnal Ilmiah Pendidikan MIPA

Vol. 9, No. 3, September 2019, pp. 191-202

p-ISSN: 2088-351X

e-ISSN: 2502-5457

DOI: http://dx.doi.org/10.30998/formatif.v9i3.3663

\title{
Analysis of Translation Understanding from Verbal to Visual on Trigonometry Concept
}

\section{Analisis Pemahaman Translasi Bentuk Verbal ke Visual pada Materi Trigonometri}

\author{
Silfanus Jelatu(*) \\ Universitas Katolik Indonesia Santu Paulus Ruteng, Jl. A. Yani No 10, Ruteng-NTT- \\ Indonesia \\ Valeria Suryani Kurnila \\ Universitas Katolik Indonesia Santu Paulus Ruteng, Jl. A. Yani No 10, Ruteng-NTT- \\ Indonesia
}

\begin{abstract}
Received: April 29, 2019
Revised: July 3, 2019

Accepted: September 2, 2019

Abstract

Constructing representations in the form of visualization can help students connect with problem situations and facilitate students' ability to communicate their understanding of the problem. This implies the ability to translate mathematical concepts. This research is a descriptive study that aims to describe the ability to translate trigonometric ideas from verbal forms to visual forms of students. This research was conducted at mathematics education of STKIP Santu Paulus Ruteng which involved 75 first-level students as a sample. The results of this study indicate that the students' at the mathematics education department of STKIP Santu Paulus Ruteng, especially in the new semester, were mostly still capable of teaching the translation of trigonometric concepts from verbal to visual forms, some of which were at the PU level with a percentage of $36 \%$. In the second level, $30.6 \%$ is in the PUSM, SU category, $17.4 \%$, NU is $13.3 \%$ and $\mathrm{SM}$ is $2.6 \%$. The results of this research can be used as references for high school teachers to find out their graduation profile in terms of translational skills and also input for lecturers to be able to adjust the lecture process based on the characteristics that have been produced.

Keywords: Translation understanding, verbal, visual, trigonometry
\end{abstract}

(*) Corresponding Author: $\quad$ silfanusjelatu@yahoo.co.id (085338384748).

How to Cite: Jelatu, S. \& Kurnila, V. S. (2019). Analysis of translation understanding from verbal to visual on trigonometry concept. Formatif: Jurnal Ilmiah Pendidikan MIPA, 9 (3): 191-202. http://dx.doi.org/10.30998/formatif.v9i3.3663

\section{PENDAHULUAN}

Kata pemahaman atau dalam bahasa Inggris understanding merupakan salah satu kata yang sering digunakan dalam banyak bentuk dan ungkapan baik dalam pembicaraan formal maupun informal. Kita dapat mengatakan bahwa seseorang 'memahami' sesuatu, kita dapat berbicara tentang 'pemahaman' seseorang tentang sesuatu, dan tentang berbagai 'pemahaman' yang mungkin dimiliki orang. Kita juga berbicara tentang "saling memahami", tentang memahami ucapan seseorang atau tulisan seseorang, tentang memahami kata, ekspresi, konsep, dan fenomena. Selanjutnya kita akan menyertakan identitas terhadap pemahaman seperti 'baik', 'dalam', 'buruk', 'kompleks', 'signifikan', 'penuh', 'tidak lengkap', 'intuitif', atau 'salah'. 
Formatif: Jurnal Ilmiah Pendidikan MIPA

Vol. 9, No. 3, September 2019, pp. 191-202

p-ISSN: 2088-351X

e-ISSN: 2502-5457

DOI: http://dx.doi.org/10.30998/formatif.v9i3.3663

Aksi memahami sesuatu atau proses pemahaman semuanya bisa diekspresikan berbeda. Hal tersebut tergantung pada apa yang akan dipahami, misalnya memahami sesuatu melalui ekspresi bahasa, diagram, konsep, teorema, teori, penilaian, pemikiran seseorang, fenomena, situasi, masalah, dan sebagainya.

Dalam konteks matematika, kita sering berbicara tentang memahami 'konsep matematika' baik secara umum atau memahami konsep matematika tertentu seperti jumlah, kuantitas, volume, fungsi, batas urutan, program linear, vektor, dan lain-lain. Sierpinska (2005) mengartikan pemahaman dalam matematika sebagai "konseptualisasi atau pemahaman konseptual". Lebih lanjut dijelaskan olehnya bahwa "other things are mentioned as objects of understanding as well". Identitas "konseptualisasi" akan melekat pada siswa, oleh atau dalam beberapa kajian disebutkan apabila seseorang sudah dapat menyatakan situasi matematika dan gambar atau diagram ke dalam bahasa, simbol, ide, dan model matematika; menjelaskan ide, situasi, dan relasi matematis secara lisan atau tulisan; mendengarkan, berdiskusi, presentasi, menulis matematika; membaca representasi matematis; dan mengungkapkan kembali suatu uraian matematis dengan bahasa sendiri (Auliya, 2016; Gardenia, 2016; Jeheman, Gunur, \& Jelatu, 2019)

Dalam beberapa dekade terakhir, penelitian tentang pembelajaran secara umum dan pembelajaran matematika secara khusus, telah secara kuat menetapkan peran penting pemahaman konseptual dalam membangun pengetahuan sebagai pedoman aktivitas manusia (Omer, 2015). Karakteristik matematika yang hierakis menjadikan pemahaman konsep sebagai konjungsi penting karena ada keterhubungan serta transitif antara konsep matematika yang satu dengan konsep matematika lainnya. Landasan penting yang harus dimiliki oleh peserta didik dalam usahanya untuk berpikir menyelesaikan permasalahan matematika maupun permasalahan dalam kehidupan sehari-hari serta mencapai kemampuan matematika pada level yang lebih tinggi, adalah kemampuan dalam memahami konsep matematika (NCTM, 2000; Ningsih, 2016). Pemahaman konsep yang kurang akan menyebabkan mereka tidak dapat membangun bukti matematika, menulis notasi matematika atau menggunakan bahasa matematika dengan benar (Ramdhani, Usodo, \& Subanti, 2017). Hal ini memberikan gambaran bahwa kemampuan pembuktian matematika terkait atau berkausalitas dengan kemampuan pemahaman matematis (Liman \& Isma'il, 2015).

Menjadi mahir dalam bidang yang kompleks seperti matematika memerlukan kemampuan untuk menggunakan pengetahuan secara fleksibel dan menerapkan apa yang dipelajari dengan tepat pada pengaturan atau keberadaan yang sesungguhnya. Kemahiran ini akan dibangun oleh sebuah komponen penting dari kecakapan matematika yakni pemahaman konseptual (NCTM, 2000).

Pemahaman konsep matematika adalah bagian fundamental yang penting dalam mencapai kemampuan memahami masalah khususnya masalah-masalah dalam kehidupan sehari-hari (Lambertus, 2016). NCTM (2000) menegaskan bahwa untuk mencapai pembelajaran yang bermakna pembelajaran matematika seharusnya diarahkan untuk mengembangkan keterampilan mengoneksikan antara ide-ide matematika yang berbeda, memahami bagaimana ide-ide matematika saling terkait satu sama lain dengan membangun pemahaman secara menyeluruh dan penggunaannya dalam konteks di luar matematika. Selain itu, ada beberapa peneliti yang menganjurkan agar mempertahankan praktik teknis berupa praktik manipulasi simbol untuk mengarah pada pemahaman konseptual simbol-simbol tersebut (Kurniati, Prahmana, Makur, \& Jelatu, 2018; Kurnila, Jau, Fedi, \& Kurniawan, 2018; Nunes \& Bryant, 2000).

Bloom, Englehard, Furst, \& Hill, (1956) menyatakan bahwa salah satu aspek yang mencirikan kemampuan pemahaman ialah translasi (translation) atau pemahaman translasi. Pemahaman translasi merupakan pemahaman dasar menuju pemahaman lain 
Formatif: Jurnal Ilmiah Pendidikan MIPA

Vol. 9, No. 3, September 2019, pp. 191-202

p-ISSN: 2088-351X

e-ISSN: 2502-5457

DOI: http://dx.doi.org/10.30998/formatif.v9i3.3663

yakni pemahaman interpretasi (interpretation), dan ekstrapolasi (extrapolation). Dengan kata lain pemahaman translasi bersifat transitif. Tabrizi \& Rideout (2017) menegaskan kembali pernyataan Bloom bahwa pemahaman penerjemahan (translation) menempati posisi transisi antara level kognitif pengetahuan (C1) dan level kogniitf lainnya seperti pemahaman (interpretasi dan ekstrapolasi/C2), aplikasi (C3), analisis (C4), sintesis (C5), dan evaluasi (C6). Lebih lanjut, pemahaman terjemahan atau translasi berarti bahwa seseorang dapat menempatkan sebuah komunikasi ke dalam bahasa yang lain, ke dalam istilah yang lain, atau ke dalam bentuk komunikasi yang lain. Pada bagian translasi ini, biasanya akan melibatkan pemberian makna ke berbagai bagian komunikasi yang diambil secara terpisah.

Menurut Ruseffendi (Susanto, 2013:210) pemahaman pengubahan (translation) digunakan untuk menyampaikan informasi dengan bahasa dan bentuk yang lain dan menyangkut pemberian makna dari suatu informasi yang bervariasi. Rosiyanti (2015) mendefinisikan pemahaman translasi dalam konteks pemahaman konsep matematika sebagai kemampuan menyatakan ulang konsep yang telah dipelajari.

Menurut Bloom et. al. (1956) pemahaman translasi meliputi kemampuan terjemahan dari satu tingkat abstraksi ke abstraksi yang lain dan terjemahan dari satu bentuk verbal ke bentuk yang lain. Penjelasan tentang kedua karakteristik pemahaman translasi tersebut dapat dijelaskan sebagai berikut.

Pertama, terjemahan dari satu tingkat abstraksi ke yang lain terdiri dari:

1) Kemampuan untuk menerjemahkan masalah yang diberikan dalam bentuk frasaologi yang abstrak menjadi frasa kurang abstrak. Proses ditandai oleh penamaan kembali masalah dengan menggunakan kata-kata sendiri.

2) Kemampuan menerjemahkan bagian komunikasi yang panjang menjadi lebih singkat atau lebih abstrak. Kemampuan untuk menerjemahkan abstraksi, seperti beberapa prinsip umum dengan memberikan ilustrasi atau contoh.

3) Terjemahan dari bentuk simbolis ke bentuk lain, atau sebaliknya.

4) Kemampuan menerjemahkan hubungan yang diekspresikan dalam bentuk simbolis, termasuk ilustrasi, peta, tabel, diagram, grafik, dan rumus matematika dan lainnya, ke bentuk verbal dan sebaliknya. Misalnya. diberikan sebuah konsep geometri dalam istilah verbal, kemudian dimanipulasi melalui penerjemahkan ke dalam istilah visual atau spasial.

5) Kemampuan untuk menyiapkan representasi grafis dari fenomena fisik atau data yang diamati atau direkam.

Kedua, terjemahan dari satu bentuk verbal ke yang lain terdiri dari:

1) Kemampuan untuk menerjemahkan pernyataannon-literal (metafora, simbolisme, ironi, berlebihan) ke bahasa yang biasa.

2) Kemampuan untuk memahami pentingnya kata-kata tertentu dari sebuah puisi berdasarkan konteksnya.

3) Kemampuan menerjemahkan (dengan atau tanpa kamus) prosa atau puisi bahasa asing ke dalam bahasa yang lain dengan baik (Bloom et al., 1956).

Dari klasifikasi tentang pemahaman translasi di atas, terlihat bahwa salah satu indikator kemampuan translasi adalah mampu mengubah istilah verbal ke dalam istilah lain yakni representasi visual. Dengan kata lain, indikasi seseorang memiliki pemahaman yakni dapat mentranslasikan representasi bentuk verbal menjadi bentuk visual. Indikator ini merupakan salah satu indikator yang menjadi dasar dalam membangun kemahiran bermatematika. Hal ini diperkuat oleh pernyataan Rahmawati, Purwanto, Subanji, Hidayanto, \& Anwar (2017) bahwa "The ability to do translation from one form of representation to another representation form is a fundamental ability to build a conceptual and mathematical thinking". Bruner juga menerangkan bahwa proses 
Formatif: Jurnal Ilmiah Pendidikan MIPA

Vol. 9, No. 3, September 2019, pp. 191-202

p-ISSN: 2088-351X

e-ISSN: 2502-5457

DOI: http://dx.doi.org/10.30998/formatif.v9i3.3663

pemecahan masalah yang sukses bergantung kepada keterampilan mempresentasikan masalah seperti mengonstruksi dan menggunakan representasi matematis dalam bentuk kata-kata, grafik, tabel, dan persamaan-persamaan, penyelesaian dan manipulasi simbol (Jelatu, Sariyasa, \& Ardana, 2018; Sari, Amir M.Z., \& Risnawati, 2017).

Selain itu, National Council of Teachers of Mathematics (NCTM, 2000) dalam buku yang berjudul Principles and Standards for School Mathematics (PSSM) mendorong guru dan siswa untuk menggunakan banyak representasi selama pengajaran matematika. NCTM (2000) menyatakan bahwa semua siswa harus "create and use representations to organize, record, and communicate mathematical ideas; select, apply, and translate among mathematical representations to solve problems; [and] use representations to model and interpret physical, social, and mathematical phenomena" (Cope, 2015). Kemampuan translasi bentuk verbal ke visual merupakan salah satu pusat pembelajaran matematika untuk mengembangkan dan menguasai matematika (Sari et. al., 2018).

Trigonometri merupakan salah satu subjek matematika yang sebagian besar konsepnya membutuhkan kemampuan visualisasi untuk memahaminya. Artinya, untuk menguasai subjektersebut pebelajar harus mampu melakukan translasi konsep trigonometri ke dalam bentuk atau ekspresi visual. Beberapa penelitian menunjukan bahwa salah satu topik yang sering menjadi masalah adalah trigonomeri dengan segenap cakupannya. Trigonometri adalah salah satu mata pelajaran sekolah yang sangat sedikit disukai dan berhasil dikuasai oleh siswa. Trigonometri juga dibenci dan diperjuangkan oleh sebagian besar siswa. Trigonometri adalah bidang matematika yang oleh siswa diyakini sangat sulit dan abstrak dibandingkan dengan mata pelajaran matematika lainnya (Gür, 2009).

Banyak penelitian yang berkaitan dengan pendidikan matematika menjelaskan bahwa siswa memiliki kesalahpahaman dan membuat kesalahan tentang trigonometri. Beberapa peneliti telah menyebutkan bahwa kompleksitas belajar merupakan penyebab terjadinya miskonsepsi serta kesalahan dalam belajar trigonometri (Orhun, 2010; Usman \& Hussaini, 2017). Namun, Ahmad, Ahmad, \& Nawawi (2010) menguraikan secara berbeda dan menyimpulkan bahwa kesulitan belajar atau kesulitan menguasai konsep trigonometri disebabkan oleh ketidakmampuan siswa dalam melakukan translasi bentuk permasalahan yang diajukan. Lebih lanjut, Ahmad et. al., (2010) menyatakan bahwa "students normally find difficulty in solving word problems initially from translating the word representations into mathematical representation.

Banyak penelitian tentang kesulitan belajar trigonometri yang telah dilakukan,pada umumnya kurang spesifik menilik pada aspek kemampuan translasi. Beberapa peneliti mempelajari masalah yang lebih spesifik dalam trigonometri seperti penyederhanaan ekspresi atau bentuk trigonometri (Chigonga, 2016; Mensah, 2017). Brown (2006) menganalisis pemahaman siswa tentang sinus dan kosinus. Dia secara khusus melihat pada aspek koneksi trigonometri. Studi ini menunjukkan bahwa banyak siswa memiliki pemahaman yang tidak lengkap atau terfragmentasi pada tiga cara utama untuk memahami sinus dan kosinus, yakni sebagai koordinat titik pada lingkaran, sebagai jarak horizontal dan vertikal yang merupakan persyaratan grafis dari koordinat tersebut, dan sebagai rasio sisi-sisi segitiga. Orhun (2010) mempelajari kesulitan yang dihadapi oleh siswa dalam menggunakan trigonometri untuk memecahkan masalah dalam trigonometri. Orhun menemukan bahwa para siswa tidak mengembangkan konsep trigonometri dengan pasti dan mereka membuat beberapa kesalahan. Metode guru-aktif dan metode menghafal memberikan pengetahuan tentang trigonometri yang hanya berlaku dalam waktu singkat, tetapi siswa tidak dapat mempertahankan pengetahuan ini untuk jangka panjang. Mensah (2017) dalam penelitiannya menyimpulkan bahwa siswa 
Formatif: Jurnal Ilmiah Pendidikan MIPA

Vol. 9, No. 3, September 2019, pp. 191-202

p-ISSN: 2088-351X

e-ISSN: 2502-5457

DOI: http://dx.doi.org/10.30998/formatif.v9i3.3663

menjawab sebagian pertanyaan di tingkat pertama dan kedua dan tidak cukup menjawab pertanyaan di tingkat lain (tinggi). Para siswa memiliki kesalahpahaman dan kompleksitas pembelajaran, yang dikaitkan dengan fakta bahwa sebelum mempelajari konsep trigonometri, siswa belajar beberapa konsep atau konsep pra-pembelajaran secara salah atau cacat. Konsep-konsep ini sangat mendasar untuk mempelajari konsep-konsep trigonometri lainnya.

Guy Brousseau (dalam Gür, 2009) mengklaim kesalahan tidak hanya dihasilkan dari ketidaktahuan, ketidakpastian, atau kebetulan seperti yang diuraikan dalam teori pengetahuan empiris. Kesalahan adalah hasil dari pengetahuan sebelumnya yang dulunya menarik dan sukses, tetapi sekarang telah terbukti salah atau tidak dapat dididik. Kesalahan semacam ini tidak teratur dan tidak dapat diprediksi letak kendala dan penyebab kesalahannya. Oleh karenanya, terkait dengan fungsi guru dan siswa, kesalahan adalah bagian dari pengetahuan yang diperoleh.

Potret tentang fakta rendahnya pemahaman konsep trigonometri di atas secara keseluruhan menggambarkan profil-profil kesulitan siswa dalam memahami konsepkonsep trigonometri yang terjadi pada siswa sekolah menengah. Dalam konteks pendidikan di Indonesia, trigonometri juga diajarkan di perguruan tinggi. Jadi, tidak menutup kemungkinan bahwa kejadian-kejadian serupa dapat dialami oleh mahasiswa pada perguruan tinggi. Teori Brousseau di atas sangat relevan untuk dijadikan landasan untuk memecahkan masalah kesulitan belajar trigonometri. Mengingat trigonometri sebagai salah satu pelajaran yang diberikan sampai pada tingkat perguruan tinggi, maka penguasaan konsep terdahulu hingga sekarang perlu diketahui. Oleh karena itu, peneliti akan menganalisis kemampuan pemahaman konsep trigonometri siswa (mahasiswa) di perguruan tinggi, khusunya pada aspek pemahaman translasi dari bentuk verbal ke dalan bentuk visual.

Tujuan dari penelitian ini adalah untuk mengidentifikasi tingkat pencapaian pemahaman mahasiswa dalam melakukan translasi atau merepresentasikan masalah matematika ke dalam bentuk visual untuk memperoleh pemecahan masalah yang utuh. Mengkonstruksi representasi dalam bentuk visual dapat membantu siswa terhubung dengan kognitifnya untuk memahami masalah dan memfasilitasi siswa untuk mengkomunikasikan pemahaman mereka tentang masalah itu.

\section{METODE}

Penelitian ini menggunakan analisis deskriptif untuk menggambarkan tingkat pemahaman translasi mahasiswa. Penelitian ini dilakukan pada semester ganjil tahun ajaran 2018/2019. Sampel dalam penelitian ini adalah seluruh mahasiswa tingkat I Program Studi Pendidikan Matematika di STKIP Santu Paulus, Ruteng, NTT. Subjek penelitian ini adalah sebanyak 75 orang mahasiswa. Peneliti secara eksplisit mengkaji tentang profil pemahaman translasi konsep trigonometri pada aspek translasi bentuk verbal ke spasial. Instrumen penelitian yang digunakan adalah berupa instrumen soal tes pemahaman konsep matematis dan rubrik penilaian. Instrumen tes yang digunakan adalah tes esai yang telah divalidasi konten oleh 4 ahli, dan instrumen yang divalidasi ini diuji pada 32 mahasiwa tingkat II Program Studi Pendidikan Matematika di STKIP Santu Paulus. Hasil tes kemudian diproses dan dianalisis untuk melihat validitas, reliabilitas, dan tingkat kesulitan soal (Cronbach dalam Nurhuda, Rusdiana, \& Setiawan, 2017). Peneliti bekerja sama dengan beberapa dosen Pendidikan Matematika STKIP Santu Paulus untuk menyusun dan melakukan uji coba insrumen. Teknik analisis data yang digunakan dalam penelitian ini adalah analisis data deskriptif kuantitatif. 
Formatif: Jurnal Ilmiah Pendidikan MIPA

Vol. 9, No. 3, September 2019, pp. 191-202

p-ISSN: 2088-351X

e-ISSN: 2502-5457

DOI: http://dx.doi.org/10.30998/formatif.v9i3.3663

Setelah tes selesai dilakukan, hasil jawaban tertulis siswa dianalisis berdasarkan lembar penilaian. Dari hasil tersebut akan dikategorikan kemampuan translasi bentuk verbal ke visual dengan ketentuan skor. Pengkategorian siswa dibagi menjadi lima kategori untuk skor total yang diperoleh berdasarkan pengkategorian menggunakan kriteria Abraham, et al. (dalam Morgil \& Yörük, 2006).

Tabel 1. Skema Evaluasi untuk Item Tes

\begin{tabular}{|c|c|c|c|}
\hline No & Skor numerik & Tingkat Pemahaman & Kriteria \\
\hline 1 & 0 & $\begin{array}{l}\text { No Understanding } \\
(N U)\end{array}$ & $\begin{array}{l}\text { Kosong, pertanyaan berulang, } \\
\text { respons tidak relevan atau tidak } \\
\text { jelas, tidak ada penjelasan yang } \\
\text { diberikan untuk jawaban } \\
\text { pilihan }\end{array}$ \\
\hline 2 & 1 & $\begin{array}{l}\text { Specific misconception } \\
(S M)\end{array}$ & $\begin{array}{l}\text { Respons yang salah secara } \\
\text { ilmiah }\end{array}$ \\
\hline 3 & 2 & $\begin{array}{l}\text { Partial understanding } \\
\text { with a specific } \\
\text { misconception } \\
(\text { PUSM) }\end{array}$ & $\begin{array}{l}\text { Respons yang menunjukkan } \\
\text { pemahaman konsep, tetapi juga } \\
\text { mengandung kesalahpahaman }\end{array}$ \\
\hline 4 & 3 & $\begin{array}{l}\text { Partial Understanding } \\
(P U)\end{array}$ & $\begin{array}{l}\text { Tanggapan yang mengandung } \\
\text { bagian dari konsep yang } \\
\text { diterima secara ilmiah }\end{array}$ \\
\hline 5 & 4 & $\begin{array}{l}\text { Sound Understanding } \\
(S U)\end{array}$ & $\begin{array}{l}\text { Tanggapan yang berisi semua } \\
\text { bagian dari konsep yang } \\
\text { diterima secara ilmiah }\end{array}$ \\
\hline
\end{tabular}

Selanjutnya, hasil skor pemahaman mahasiswa dideskripsikan dalam bentuk persentase hasil berdasarkan proporsi mahasiswa ke dalam lima kategori di atas. Hal ini bertujuan untuk mendeskripsikan tentang kecendrungan level pemahaman mahasiswa dalam melakukan transasi bentuk verbal ke visual pada konsep trigonometri.

\section{HASIL DAN PEMBAHASAN}

\section{Hasil}

Dalam melakukan pengujian validitas isi, peneliti menggunakan indeks validitas Aiken (Retnawati, 2016). Dari hasil perhitungan indeks V, suatu butir atau perangkat dapat dikategorikan berdasarkan indeksnya. Jika indeksnya kurang atau sama dengan 0,4 dikatakan validitasnya kurang, jika indeksnya 0,4-0,8 dikatakan validitasnya sedang, dan jika lebih besar dari 0,8 dikatakan sangat valid. Tabel 2 menunjukkan hasil validitas konten instrumen yang divalidasi oleh 4 validator. Dari 8 item yang divalidasi, soal dinyatakan tidak valid sebanyak 3 butir, 1 validitas sedang, dan 4 butir dengan kategori validitas tinggi. 
Formatif: Jurnal Ilmiah Pendidikan MIPA

Vol. 9, No. 3, September 2019, pp. 191-202

p-ISSN: 2088-351X

e-ISSN: 2502-5457

DOI: http://dx.doi.org/10.30998/formatif.v9i3.3663

Tabel 2. Hasil Validasi Konten

\begin{tabular}{cccccccccccc}
\hline No Soal & Val.1 & Val.2 & Val.3 & Val.4 & $s_{1}$ & $s_{2}$ & $s_{3}$ & $s_{4}$ & $\sum s$ & V & Ket. \\
\hline 1 & 5 & 4 & 5 & 5 & 4 & 3 & 4 & 4 & 15 & 0,9375 & SV \\
\hline 2 & 4 & 4 & 4 & 4 & 3 & 3 & 3 & 3 & 12 & 0,75 & V \\
\hline 3 & 5 & 4 & 5 & 5 & 4 & 3 & 4 & 4 & 15 & 0,9375 & SV \\
\hline 4 & 2 & 3 & 2 & 3 & 1 & 2 & 1 & 2 & 6 & 0,375 & TV \\
\hline 5 & 4 & 4 & 5 & 5 & 3 & 3 & 4 & 4 & 14 & 0,875 & SV \\
\hline 6 & 2 & 2 & 2 & 1 & 1 & 1 & 1 & 0 & 3 & 0,1875 & TV \\
\hline 7 & 4 & 4 & 4 & 5 & 3 & 3 & 3 & 4 & 13 & 0,8125 & SV \\
\hline 8 & 2 & 2 & 3 & 3 & 1 & 1 & 2 & 2 & 6 & 0,375 & TV \\
\hline
\end{tabular}

Tabel 3 menunjukkan hasil validasi instrumen setelah dilakukan validasi konten yang telah direduksi menjadi 5 pertanyaan. Berdasarkan validasi instrumen, instrumen (5 pertanyaan tes esai) dapat mengukur apa yang diukur dan konsisten (ajeg) ketika diuji dalam sampel yang berbeda. George \& Mallery (2003) memberikan aturan praktis atau kriteria penenentuan validitas dan reliabilitas dalam bentuk kriteria "apabila Value $\geq .9=$ sangat bagus, $\geq .8$ =Bagus, $\geq .7=$ terima, $\geq .6=$ Dipertanyakan, $\geq .5=$ Kurang bagus, dan $\leq .5=$ Tidak Dapat Diterima".

Tabel 3. Hasil Validasi dan reliabilitas

\begin{tabular}{clll}
\hline No & Ukuran Deskriptif & Value & Kriteria \\
\hline 1 & Validitas & .92 & Sangat Bagus \\
2 & Reliabilitas & .86 & Bagus \\
\hline
\end{tabular}

Tabel 4 menunjukkan gambaran umum tingkat pemahaman mahasiswa dalam melakukan translasi bentuk verbal ke bentuk visual konsep trigonometri setelah dipersentasekan berdasarkan proporsi mahasiswa.Secara keseluruhuan tingkat pemahaman mahasiswa terbanyak berada pada kategori $P U$ yakni sebesar $36 \%$, sedangkan total mahasiswa yang berada pada level SUhanya sebesar $17,6 \%$.

Tabel 4. Persentase Pemahaman Mahasiswa

\begin{tabular}{clcc}
\hline No & Level Pemahaman & Jumlah Mhswa & Persentase \\
\hline 1 & NU & 10 & $13,3 \%$ \\
2 & SM & 2 & $2,6 \%$ \\
3 & $P U S M$ & 23 & $30,6 \%$ \\
4 & $P U$ & 27 & $36 \%$ \\
5 & $S U$ & 13 & $17,4 \%$ \\
\hline
\end{tabular}

Sedangkan bila dipresentasekan berdasarkan masing-masing soal, maka hasilnya dapat dilihat pada tabel 5 berikut. Tabel 5 menerangkan bahwa pada soal nomor 2, 4 dan 5 tidak ada (0\%) mahasiswa yang menunjukan respon yang salah secara ilmiah $(S M)$. 
Formatif: Jurnal Ilmiah Pendidikan MIPA

Vol. 9, No. 3, September 2019, pp. 191-202

p-ISSN: 2088-351X

e-ISSN: 2502-5457

DOI: http://dx.doi.org/10.30998/formatif.v9i3.3663

Tabel 5. Persentase Pemahaman Mahasiswa Hasil Tes Per Soal

\begin{tabular}{lrrlll}
\hline \multicolumn{5}{c}{ No Soal } \\
\hline Level Pemahaman & 1 & \multicolumn{1}{c}{2} & \multicolumn{1}{c}{3} & \multicolumn{1}{c}{4} & \multicolumn{1}{c}{5} \\
\hline NU & $8,00 \%$ & $4,67 \%$ & $14,67 \%$ & $10,67 \%$ & $20,00 \%$ \\
SM & $5,33 \%$ & $0,00 \%$ & $5,33 \%$ & $2,67 \%$ & $0,00 \%$ \\
$P U S M$ & $17,33 \%$ & $16,00 \%$ & $49,33 \%$ & $34,67 \%$ & $34,67 \%$ \\
$P U$ & $36,00 \%$ & $65,33 \%$ & $25,33 \%$ & $30,67 \%$ & $20,00 \%$ \\
$S U$ & $33,33 \%$ & $4,00 \%$ & $5,33 \%$ & $21,33 \%$ & $25,33 \%$ \\
\hline
\end{tabular}

\section{Pembahasan}

Secara umum, tujuan utama dalam penelitian ini adalah mendeskripsikan profil pemahaman mahasiswa tentang konsep trigonometri. Peneliti meruncing lebih tajam lagi penelitian ini pada aspek pemahaman translasi konsep trigonometri dari bentuk verbal ke dalam bentuk visual. Untuk sampai pada tujuan itu, peneliti telah menderetkan lima kriteria yang akan mendeskripsikan level pemahaman mahasiswa tersebut. Kelima kriteria tersebut diadopsi dari kriteria pemahaman menurut Abraham, et. al. (dalam Morgil \& Yörük, 2006) yaitu: 1) No Understanding (NU) yakni siswa tidak memiliki pemahaman yang diinterpretasikan dalam bentuk jawaban kosong, pertanyaan berulang, respons tidak relevan atau tidak jelas, tidak ada penjelasan yang diberikan untuk jawaban pilihan, 2) Specific misconception (SM) yakni siswa mampu memberikan respon, tetapi salah secara ilmiah, 3) Partial understanding with a specific misconception (PUSM) yakni mahasiswa mampu memberikan respons yang menunjukkan pemahaman konsep, tetapi juga mengandung kesalahpahaman, 4) Partial Understanding (PU)yakni mahasiswa mampu memberikan tanggapan yang mengandung bagian dari konsep yang diterima secara ilmiah, 5) SoundUnderstanding (SU)yakni mahasiswa mampu memberikan tanggapan yang berisi semua bagian dari konsep yang diterima secara ilmiah.

Peneliti menggunakan 5 butir soal uraian. Hasil penelitian ini menunjukan bahwa mahasiwa pendidikan matematika STKIP Santu Paulus Ruteng khususnya pada semester pertama sebagian besar masih berada pada kategori sedang atau dengan kata lain mereka memiliki kemampuan pemahaman translasi bentuk verbal ke visual, tetapi belum sampai pada tahap sempurna. Kemampuan pemahaman translasi konsep trigonometri dari bentuk verbal ke visual sebagian besar berada pada level $P U$ dengan persentase sebesar $36 \%$. Pada tingkatan kedua sebesar 30,6\% berada pada kategori PUSM, SU 17,6\%, NU 13,8\% dan $S M$ 2,6\%. Hasil penelitian ini memiliki kesamaan dengan penelitian Rahmawati et. al.(2017) yang menyimpulkan bahwa pelajar mampu melakukan proses translasi dari bentuk verbal ke dalam bentuk visual berupa grafik dengan baik. Selain itu, hasil penelitian Suraji, Maimunah, \& Saragih (2017) yang dilakukan di sekolah menengah menunjukan bahwa pada salah satu indikator pemahaman matematika yakni indikator kemampuan siswa dalam menyajikan konsep dalam berbagai bentuk representasi matematis, kesalahan siswa tergolong sangat rendah yaitu sebesar 4,76\%. Kesalahan ini meliputi kesalahan siswa dalam merepresentasikan konsep SPLDV ke dalam bentuk matematis.

Menilik pada hasil pekerjaan siswa secara umum, peneliti menemukan bahwa beberapa mahasiswa mampumengekstrakinformasi atau soal yang diberikan ke dalam bentuk gambar. Transformasi komunikasi yang tepat dilakukan oleh mahasiswa ini selanjutnya memberikan gambaran yang positif dalam melakukan eksplorasi terhadap gambar yang mereka hasilkan. Artinya mahasiswa mampu mengonstruksi kembali 
Formatif: Jurnal Ilmiah Pendidikan MIPA

Vol. 9, No. 3, September 2019, pp. 191-202

p-ISSN: 2088-351X

e-ISSN: 2502-5457

DOI: http://dx.doi.org/10.30998/formatif.v9i3.3663

informasi dalam bentuk representasi yang berbeda yakni representasi visual dan mampu menginterpretasi kelanjutan dari permasalah yang diberikan.

Jika diamati secara spesifik pada masing-masing butir soal, terdapat tiga soal yakni pada soal no 2, 3 dan 5 yang memberikan gambaran bahwa terdapat banyak mahasiswa yang tak dapat menunjukan kemampuan translasi mereka dengan baik. Tingkat kesalahan yang paling banyak dilakukan oleh mahasiswa terdapat pada soal no 5 yakni sebanyak 20\%. Artinya ada banyak mahasiswa yang tidak mampu melakukan translasi atau berkategori $N U$. Hasil analisis terhadap jawaban mereka menunjukan bahwa terdapat kegagalan untuk memecahkan masalahyang direfleksikan melalui kegagalan memahami masalah bahkan kegagalan memahami istilah matematika dalam soal yang diajukan. Temuan ini diperkuat oleh hasil penelitian Norasiah (dalam Usman \& Hussaini, 2017) dimana siswa yang bermasalah atau gagal menerjemahkan masalah matematika (verbal) ke dalam bentuk matematika (simbol matematika, visualisasi) juga memiliki masalah dalam memahami istilah khusus dalam matematika. Lebih lanjut Usman \& Hussaini (2017) menjelaskan bahwa kegagalan ini dapat disebabkan oleh kurangnya penekanan pada pemahaman bahasa trigonometri dan keterampilan yang dibutuhkan.

Pada soal no 2 dan 3 secara bersama-sama memberikan persentase $15 \%$ pada level $N U$. Dari analisis lebih lanjut pada jawaban mahasiswa, peneliti menemukan bahwa beberapa siswa memiliki kesalahpahaman dalam membuat representasi visual dari pertanyaan yang diberikan. Pada salah satu soal tentang masalah perjalanan kapal laut, sebanyak $15 \%$ mahasiswa tidak mampu melukis arah perjalanan kapal dengan baik sesuai dengan istruksi. Akibatnya mereka tidak mampu menyelesaikan soal dengan benar. Namun, beberapa mahasiswa juga menunjukkan bahwa mereka telah mengonstruksi gambar selama penyelesaian masalah tetapi gambar yang mereka hasilkan tidak sepenuhnya konkret sehingga tidak memberikan dukungan kepada mereka dalam melanjutkan proses pemecahan masalah atau penyelesaian akhir dari soal.

Hasil penelitian ini memberikan rekomendasi bahwa menerjemahkan soal ke dalam bahasa lain yakni bentuk visual membuat soal atau masalah dapat lebih mudah dipahami. Hal ini sesuai dengan pendapat Nathan (dalam Ramdhania et al., 2017) yang menyatakan bahwa ketidakmampuan untuk menghubungkan aspek-aspek konseptual matematika, ketidakmampuan untuk memahami hubungan antara informasi, pemahaman yang tidak lengkap tentang bahasa matematika dan kesulitan dalam memahami dan memvisualisasikan konsep matematika dapat mengakibatkan kesulitandalam memberikan interpretasi dan eksplorasi dalam menyelesaikan permasalahan matematika.

Temuan ini dapat dijadikan masukan bagi para guru sekolah menengah dan dosen dalam memepersiapkan atau mengembangkan pemahaman konsep trigonometri pebelajar. Sebagaimana rekomendasi padapenelitian sebelumnya yang menyarankan pembelajaran berbasis visualisasi agar benar-benar dimasukan dalam membantu proses pembelajaran (Ahmad et. al. 2010). Banyak yang harus dilakukan dalam meningkatkan penguasaan dan pemahaman konsep trigonometri, diantaranya adalah bagaimana visualisasi dapat diintegrasikan dalam pengajaran dan pembelajaran matematika di ruang kelas. Seperti yang Woolner (2004) tunjukkan bahwa pedagogi efektif yang dapat meningkatkan penggunaan dan kekuatan visualisasi dalam pendidikan matematika mungkin merupakan masalah yang mendesak dan perlu penekanan lebih lanjut. Cara atau strategi untuk memfasilitasi visualisasi dalam pengajaran dan pembelajaran matematika harus diperhatikan. 
Formatif: Jurnal Ilmiah Pendidikan MIPA

Vol. 9, No. 3, September 2019, pp. 191-202

p-ISSN: 2088-351X

e-ISSN: 2502-5457

DOI: http://dx.doi.org/10.30998/formatif.v9i3.3663

\section{PENUTUP}

Hasil penelitian ini menunjukan bahwa kemampuan pemahaman translasi konsep trigonometri dari bentuk verbal ke visual mahasiwa pendidikan matematika STKIP Santu Paulus Ruteng khususnya pada semester baru, sebagian besar masih berada pada level $P U$ dengan persentase sebesar 36\%. Pada tingkatan kedua sebesar 30,6\% berada pada kategori PUSM, SU 17,3\%, NU 13,8\%, dan SM 2,6\%.

\section{DAFTAR PUSTAKA}

Ahmad, A., Tarmizi, R. A., \& Nawawi, M. (2010). Visual representations in mathematical word problem solving among form four students in Malacca. Procedia - Social and Behavioral Sciences, 8, 356-361. https://doi.org/10.1016/j.sbspro.2010.12.050

Auliya, R. N. (2016). Kecemasan matematika dan pemahaman matematis. Formatif: Jurnal Ilmiah Pendidikan MIPA, 6(1), 12-22. https://doi.org/10.30998/formatif.v6i1.748

Bloom, B. S., Englehard, M. D., Furst, E. J., \& Hill, W. H. (1956). Taxonomy of educational objectives: The classification of educational goals: Handbook I, cognitive domain. London: Longmans. https://doi.org/10.1300/J104v03n01_03

Brown, S. A. (2006). The trigonometric connection: students' understanding of sine and cosine. In Proceedings of the 30th Conference of the International Group for the Psychology of Mathematics Education (pp. 49-63). Prague: Charles University.

Chigonga, B. (2016). Learners' errors when solving trigonometric equations and suggested interventions from grade 12 mathematics teachers. In International Society for Technology in Education (pp. 163-176). South Africa: University of South Africa.

Cope, L. (2015). Math manipulatives: Making the abstract tangible. Delta Journal of Education, 5(1), 10-19. Retrieved from http://www.deltastate.edu/PDFFiles/DJE/spring-2015/dje_spring_2015_copefinal.pdf

Gardenia, N. (2016). Peningkatan kemampuan pemahaman dan komunikasi matematis siswa SMK melalui pembelajaran konstruktivisme model Needha. Formatif: Jurnal Ilmiah Pendidikan MIPA, 6(2), 110-118. https://doi.org/10.30998/formatif.v6i2.944

George, D., \& Mallery, P. (2003). SPSS for Windows step by step: A simple guide and reference. 11.0 update (4th ed.). Boston: Allyn \& Bacon.

Gür, H. (2009). Trigonometry learning. New Horizons in Education,57(1), 67-80. Retrieved from http://www.hkta1934.org.hk/NewHorizon/abstract/2009May/6.pdf

Jeheman, A. A., Gunur, B., \& Jelatu, S. (2019). Pengaruh pendekatan matematika realistik terhadap pemahaman konsep matematika siswa. Mosharafa: Jurnal Pendidikan Matematika, 8(2), 191-202. https://doi.org/10.31980/mosharafa.v8i2.454

Jelatu, S., Sariyasa, S., \& Ardana, I. M. (2018). Effect of geogebra-aided REACT strategy on understanding of geometry concepts. International Journal of Instruction, 11(4), 325-336. https://doi.org/10.12973/iji.2018.11421a

Kurniati, K., Prahmana, R. C. I., Makur, A. P., \& Jelatu, S. (2018). Math Comics, Vectors, and the Strategy of Preview, Question, Read, Reflect, Recite, Review (PQ4R). Formatif: Jurnal Ilmiah Pendidikan MIPA, 8(3), 159-174. https://doi.org/10.30998/formatif.v8i3.2716 
Formatif: Jurnal Ilmiah Pendidikan MIPA

Vol. 9, No. 3, September 2019, pp. 191-202

p-ISSN: 2088-351X

e-ISSN: 2502-5457

DOI: http://dx.doi.org/10.30998/formatif.v9i3.3663

Kurnila, V. S., Jau, M. A., Fedi, S., \& Kurniawan, Y. (2018). Pemecahan masalah dengan pendekatan saintifik dan koperatif tipe NHT, serta peningkatan kemampuan komunikasi matematika siswa SMP. Jurnal Review Pembelajaran Matematika, 3(2), 132-145. https://doi.org/10.15642/jrpm.2018.3.2.132-145

Lambertus. (2016). Developing skills understanding of mathematical. International Journal of Education and Research, 4(7), 315-326. Retrieved from https://www.ijern.com/journal/2016/July-2016/25.pdf

Liman, M. A., \& Isma'il, Y. (2015). Relationship between remembering, understanding and applying of Bloom taxonomy's cognitive domain and students academic achievement in mathematics. IIUM Journal of Educational Studies, 3(1), 70-91. https://doi.org/10.31436/ijes.v3i1.60

Mensah, F. S. (2017). Ghanaian Senior High School students, error in learning of trigonometry. International Journal on Environtmental \& Science Education, 12(8), 1709-1717. Retrieved from http://www.ijese.net/makale/1934

Morgil, İ., \& Yörük, N. (2006). Cross-age study of the understanding of some concepts in chemistry subjects in science curriculum. Journal of Turkish Science Edication, 3(1), 15-27. https://doi.org/10.1039/B5RP90013A

NCTM. (2000). Principles and Standards for School Mathematics. VA: NCTM.

Ningsih, Y. L. (2016). Kemampuan pemahaman konsep matematika mahasiswa melalui penerapan lembar aktivitas mahasiswa (LAM) berbasis teori APOS pada materi turunan. Edumatica, 06(April), 1-8. https://doi.org/10.1063/1.4944618

Nunes, T., \& Bryant, P. (2000). Learning and Teaching Mathematics, An International Perspective. UK: Psychology Press.

Nurhuda, T., Rusdiana, D., \& Setiawan, W. (2017). Analyzing students' level of understanding on kinetic theory of gases. Journal of Physics: Conference Series, 812(11), 012105. https://doi.org/10.1088/1742-6596/812/1/012105

Omer, F. C. (2015). Students perceptions and development of conceptual understanding regarding trigonometry and trigonometric function. Educational Research and Reviews, 10(3), 338-350. https://doi.org/10.5897/ERR2014.2017

Orhun, N. (2010). Student's mistakes and misconceptions on teaching of trigonometry. Journal of Curriculum Studies, 32(1), 208-211. Retrieved from http://dipmat.math.unipa.it/ grim/AOrhun.PDF

Rahmawati, D., Purwanto, Subanji, Hidayanto, E., \& Anwar, R. B. (2017). Process of mathematical representation translation from verbal into graphic. International Electronic Journal of Mathematics Education, 12(3), 367-381. Retrieved from https://www.iejme.com/article/process-of-mathematical-representation-translationfrom-verbal-into-graphic

Ramdhani, M. R., Usodo, B., \& Subanti, S. (2017). Student's mathematical understanding ability based on self-efficacy. In Journal of Physics: Conference Series (Vol. 909). https://doi.org/10.1088/1742-6596/909/1/012065

Retnawati, H. (2016). Analisis Kuantitatif Instrumen Penelitian (Panduan Peneliti, Mahasiswa, dan Psikometrian) Pengembangan. Yogyakarta: Parama Publishing.

Rosiyanti, H. (2015). Implementasi pendekatan pembelajaran konstruktivisme terhadap pemahaman konsep matematika mahasiswa materi transformasi linier. Jurnal Pendidikan Matematika Dan Matematika, 1(2), 59-70. https://doi.org/https://doi.org/10.24853/fbc.1.2.25-36

Sari, R. M., Amir M.Z., Z., \& Risnawati, R. (2017). Rengembangan lembar kerja siswa (LKS) berbasis pendekatan realistic mathematic education (RME) untuk memfasilitasi kemampuan representasi matematis siswa SMP. Formatif: Jurnal Ilmiah Pendidikan MIPA, 7(1), 66-74. https://doi.org/10.30998/formatif.v7i1.1108 
Formatif: Jurnal Ilmiah Pendidikan MIPA

Vol. 9, No. 3, September 2019, pp. 191-202

p-ISSN: 2088-351X

e-ISSN: 2502-5457

DOI: http://dx.doi.org/10.30998/formatif.v9i3.3663

Sierpinska, A. (2005). Understanding in Mathematics. London • Washington, D.C: The Falmer Press.

Suraji, Maimunah, \& Saragih, S. (2017). Analisis kemampuan pemahaman konsep matematis dan kemampuan pemecahan masalah matematis siswa SMP pada materi sistem persamaan linear dua variabel (SPLDV). Suska Journal of Mathematics Education, 3(2), 130. https://doi.org/http://dx.doi.org/10.24014/sjme.v4i1.5057

Susanto, A. (2013). Teori Belajar dan Pembelajaran di Sekolah Dasar (Pertama). Jakarta: Prenadamedia Group.

Tabrizi, S., \& Rideout, G. (2017). Active learning: Using Bloom's taxonomy to support critical pedagogy. International Journal for Cross-Disciplinary Subjects in Education (IJCDSE), 8(3), 3202-3209. https://doi.org/10.20533/ijcdse.2042.6364.2017.0429

Usman, M. H., \& Hussaini, M. M. (2017). Analysis of students' error in learning of trigonometry among senior secondary school students in Zaria Metropolis, Nigeria. IOSR Journal of Mathematics, 13(02), 01-04. https://doi.org/10.9790/57281302040104

Woolner, P. (2004). A comparison of a visual-spatial approach and a verbal approach to teaching mathematics. In Proceedings of the 28th Conference of the International Group for Psychology of Mathematics Education (PME). (Vol. 4, pp. 449-456). Bergen: Bergen University College. 